\title{
Short Communication: Carora Cattle Show High Variability in $\alpha_{\mathrm{s} 1}$-Casein
}

\author{
A. Caroli, ${ }^{* 1}$ S. Chessa,† F. Chiatti,† D. Rignanese,† B. Meléndez,† R. Rizzi,† and G. Ceriotti† \\ *Dipartimento di Scienze Biomediche e Biotecnologie, Universitá degli Studi di Brescia, Viale Europa 11, 25123 Brescia, Italy \\ †Dipartimento di Scienze e Tecnologie Veterinarie per la Sicurezza Alimentare, Universitá degli Studi di Milano, Via Trentacoste 2, \\ 20134 Milano, Italy \\ ‡Facultad de Ciencias Veterinarias, Universidad Central de Venezuela, Maracay, Edo. Aragua, Venezuela
}

\section{ABSTRACT}

The objective of this study was to analyze the genetic variability of milk proteins of the Carora, a shorthorned Bos taurus cattle breed in Venezuela and in other Southern American countries that is primarily used for milk production. A total of 184 individual milk samples were collected from Carora cattle in 5 herds in Venezuela. The milk protein genes $\alpha_{\mathrm{s} 1}$-casein $(\mathrm{CN})$ (CSN1S1), $\beta$-CN (CSN2), $\kappa$-CN (CSN3), and $\beta$-lactoglobulin $(L G B)$ were typed at the protein level by isoelectrofocusing. It was necessary to further analyze CSN1S1 at the DNA level by a PCR-based method to distinguish $C S N 1 S 1 * G$ from $B$. Increased variation was found in particular at the CSN1S1 gene, where 4 variants were identified. The predominant variant was $C S N 1 S 1^{*} B$ (frequency $=0.8$ ). The second most common $C S N 1 S 1$ variant was $C S N 1 S 1 * G(0.101)$, followed by $C S N 1 S 1^{*} C(0.082)$. Moreover, a new isoelectrofocusing pattern was identified, which may result from a novel CSN1S1 variant, named $C S N 1 S 1 * I$, migrating at an intermediate position between $\operatorname{CSN} 1 S 1{ }^{*} B$ and CSN1S1*C. Six cows carried the variant at the heterozygous condition. For the other loci, predominance of $C S N 2 * A^{2}(0.764), C S N 3 * B(0.609)$, and $L G B * B(0.592)$ was observed. Haplotype frequencies (AF) at the CSN1S1-CSN2-CSN3 complex were also estimated by taking association into account. Only 7 haplotypes showed AF values $>0.05$, accounting for a cumulative frequency of 0.944 . The predominant haplotype was $B-A^{2}-B$ (frequency $\left.=0.418\right)$, followed by $B-A^{2}-A(0.213)$. The occurrence of the $G$ variant is at a rather high frequency, which is of interest for selection within the Carora breed because of the negative association of this variant with the synthesis of the specific protein. From a cheese-making point of view, this variant is associated with improved milk-clotting parameters but is negatively associated with cheese ripening.

Received June 6, 2007.

Accepted September 11, 2007.

${ }^{1}$ Corresponding author: caroli@med.unibs.it
Thus, milk protein typing should be routinely carried out in the breed, with particular emphasis on using a DNA test to detect the $C S N 1 S^{*} G$ variant. The $C S N 1 S^{*} G$ allele is likely to have descended from the Brown Swiss, which contributed to the Carora breed and also carries this allele.

Key words: milk protein, Carora cattle, Venezuela, $\alpha_{\mathrm{s} 1}$-casein

The $\alpha_{\mathrm{sl}} \mathrm{CN}$ family constitutes up to $40 \%$ of the CN fraction in bovine milk and consists of major and minor components (Farrell et al., 2004). Thompson et al. (1962) demonstrated polymorphism at $\alpha_{\mathrm{s} 1}$-CN for the first time by using starch gel electrophoresis at alkaline $\mathrm{pH}$. Since then, many other methods have been developed to evaluate bovine milk protein polymorphisms. In the Bos taurus species, the major genetic variability has been identified, at the protein level, at $\beta-\mathrm{CN}, \kappa-\mathrm{CN}$, and $\beta-\mathrm{LG}$, respectively, coded by the $C S N 2, C S N 3$, and $L G B$ genes (for a review, see Formaggioni et al., 1999).

Farrell et al. (2004) classified $8 \alpha_{\mathrm{sl}^{-}} \mathrm{CN}$ variants in the last revision of milk protein polymorphism nomenclature (Table 1 ). The highly predominant variant in B. taurus is $C S N 1 S 1^{*} B$, as first recognized by Thompson et al. (1962), which occurs with a frequency of at least 90 to $95 \%$ in many taurine breeds, including some breeds that are fixed for the allele (Formaggioni et al., 1999). The $C$ variant (Thompson et al., 1962) usually occurs at much lower frequencies in taurine breeds, but has been reported to be as high as 0.15 to 0.25 in the Jersey, Guernsey, Normande, Italian Brown, Reggiana, and Modenese (Formaggioni et al., 1999). Surprisingly, a frequency of 0.145 was found for the $C$ variant in Swedish Holsteins (Lundén et al., 1997). Moreover, the $C$ variant occurs with a high frequency in Bos indicus and Bos grunniens (Eigel et al., 1984).

The other CSN1S1 variants are rare and described only in particular breeds. The $A$ and $D$ variants were first recognized in the Holstein-Friesian (Thompson et al., 1962) and Flamande breed (Grosclaude et al., 1966), respectively. The $E$ variant has been reported only in B. grunniens (Grosclaude et al., 1976). More 
Table 1. Amino acid differences among the $\alpha_{\mathrm{Sl}^{-}} \mathrm{CN}$ (CSN1S1) variants $^{1}$

\begin{tabular}{|c|c|c|c|c|c|c|}
\hline \multirow{2}{*}{$\begin{array}{l}C S N 1 S 1 \\
\text { variant }\end{array}$} & \multicolumn{6}{|c|}{ Position and $\mathrm{AA}$ in the mature protein } \\
\hline & $14-26$ & 53 & $51-58$ & 59 & 66 & 192 \\
\hline B & & Ala & & Gln & Ser $\mathrm{P}$ & Glu \\
\hline$A$ & Deleted & & & & & \\
\hline$C$ & & & & & & Gly \\
\hline$D$ & & Thr P & & & & \\
\hline$E$ & & & & Lys & & Gly \\
\hline$F$ & & & & & Leu & \\
\hline$G$ & & & & & & \\
\hline$H$ & & & Deleted & & & \\
\hline
\end{tabular}

${ }^{1}$ Modified from Farrell et al. (2004).

recently, variants $F, G$, and $H$ were identified in $B$. taurus German Black and White cattle (Erhardt, 1993), Italian Brown cows (Mariani et al., 1993), and Kuri cattle in Chad (Mahé et al., 1999), respectively. The biochemical differences among the $8 C S N 1 S 1$ variants are summarized in Table 1. Particular emphasis must be given to the $G$ variant. The mature protein is not different from the $B$ variant; thus, $C S N 1 S 1^{*} G$ is not a protein variant from a qualitative point of view. However, $\alpha_{\mathrm{s} 1}-\mathrm{CN}$ is synthesized at a lower amount because of an insertion of $371 \mathrm{bp}$ in the 19th exon; this insertion is a relict of long-interspersed elements (LINE) of retropositional origin (Rando et al., 1992). The bovine $C S N 1 S 1{ }^{*} G$ is analogous to the goat CSN1S1*E (Grosclaude et al., 1987), showing an insertion with similar structure and quantitative effect, always within the 19th exon but in another position (Jansá-Pérez et al., 1994).

This work aimed at analyzing milk protein genetic polymorphisms in the Carora, and focusing on the high variability identified at the CSN1S1 level. Carora is a short-horned B. taurus cattle breed raised in Venezuela and other Southern American countries, mainly for milk production (ASOCRICA, 2007). The coat color varies from white to yellow. It is a synthetic breed developed in west-central Venezuela by using Brown Swiss semen on the local Criollo population (Ganado Criollo de Quebrada Arriba). This process started in the 1930s, with semen coming from Europe and North America. Later, crossbred bulls were used to maintain characteristics of adaptation to the tropical environment (Cerutti et al., 2006). The breeders' association ASOCRICA (Asociación de Criadores de la Raza Carora) was created in 1979 and Carora dairy cattle were officially recognized in 1982 (Raza Carora, 2007). Carora cattle are bred in a tropical environment with a large range of average temperatures, from 22 to $38^{\circ} \mathrm{C}$, and with relative humidity up to $90 \%$. Carora cows are reared under different production systems, from
Table 2. Allele frequencies at $\alpha_{\mathrm{s} 1} \mathrm{CN}$ (CSN1S1), $\beta$-CN (CSN2), $\kappa$ $\mathrm{CN}$ (CSN3), and $\beta$-LG (LGB) loci in the Carora breed sample $(\mathrm{n}=$ 184)

\begin{tabular}{llc}
\hline Locus & Allele & Frequency \\
\hline CSN1S1 & $B$ & 0.802 \\
& $C$ & 0.082 \\
& $G$ & 0.101 \\
CSN2 & $I$ & 0.016 \\
& $A^{1}$ & 0.084 \\
& $A^{2}$ & 0.764 \\
CSN3 & $B$ & 0.149 \\
& $C$ & 0.003 \\
& & \\
LGB & $A$ & 0.391 \\
& $B$ & 0.609 \\
& $A$ & 0.408 \\
& $B$ & 0.592 \\
\hline
\end{tabular}

extensive systems, characterized by grazing and handmilking in the presence of the calf, to intensive systems with high yields, machine milking, and concentrate supplementation. The primary selection objective is improving milk production in terms of quantity and quality. A second objective is uniformity of morphology to breed standards, considering that several types of crosses are included in the herdbook. Particular attention is given to improving the reliability of genetic evaluations in the tropical farming conditions. Since 1995, Carora bulls have been used in Holstein herds to obtain a productive animal adapted to the tropical climate. In addition, Carora bulls are mated today to $B$. indicus cows with the aim of obtaining dual-purpose animals (Cerutti et al., 2006).

A total of 184 individual milk samples were randomly collected from Carora cows in 5 herds in Venezuela. Milk samples were analyzed by isoelectrofocusing (IEF) according to Erhardt et al. (1998). On the basis of the observed phenotypes at CSN1S1, and mainly of the occurrence of the $G$ variant in the heterozygous condition (genotype $C G$ ), it was deemed necessary to further analyze CSN1S1 variation at the DNA level to distinguish the $C S N 1 S 1{ }^{*} G$ and $B$ alleles. A commercial kit (GFX Genomic Blood DNA Purification kit, Amersham Biosciences, Piscataway, NJ) was used to extract DNA directly from milk. The $G$ allele was typed by a PCR-based method (Rando et al., 1998). Allele frequencies were estimated by direct count. Frequencies at the CN haplotype (CSN1S1-CSN2-CSN3) were evaluated by using the EH program (Xie and Ott, 1993) on a sub-data set of 173 samples, considering alleles with frequencies greater than 0.05 .

Allele frequencies at CSN1S1, CSN2, CSN3, and $L G B$ are shown in Table 2. At CSN1S1, 3 known variants $(B, C, G)$ were identified. The predominant vari- 


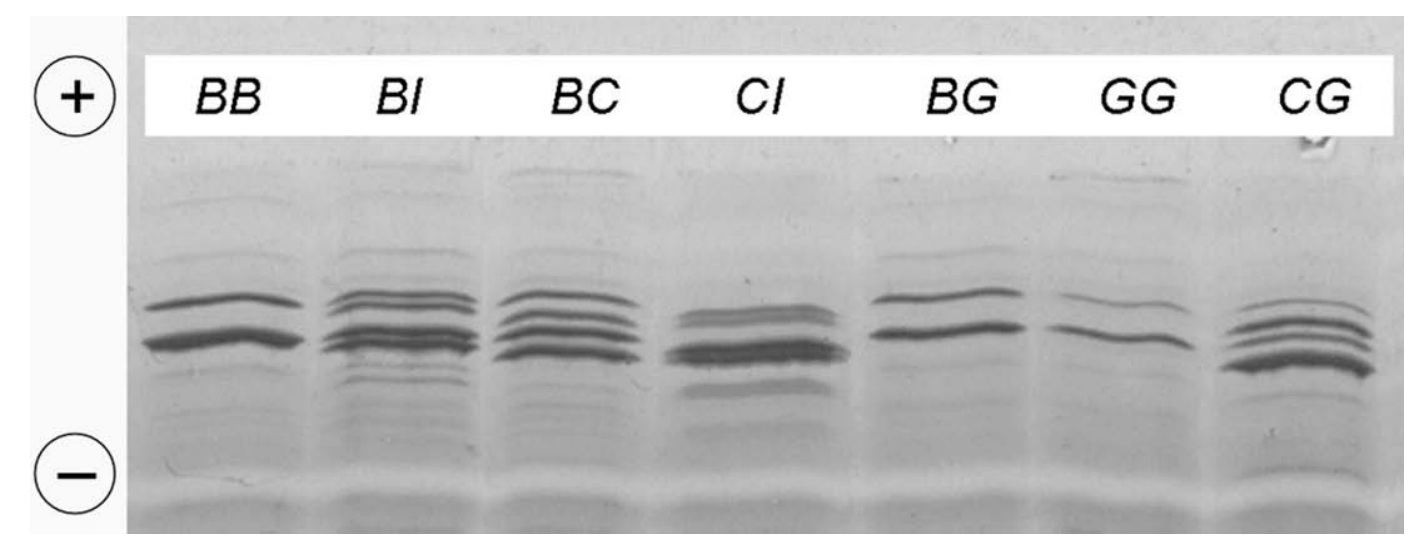

Figure 1. Isoelectrofocusing (IEF) $\alpha_{\mathrm{sl}} \mathrm{CN}$ (CSN1S1) patterns of Carora milk samples showing different CSN1S1 genotypes (listed at the top of the illustration). The $C I$ genotype belongs to a reference sample from the Banyo Gudali breed. The $B I$ and $C I$ samples show the novel migrating pattern $I$, intermediate between the $B$ and $C$ variants. The ascending order of the isoelectric point for the different alleles is $B /$ $G, I, C$.

ant was $C S N 1 S 1^{*} B$, as expected in $B$. taurus breeds. The frequency was approximately 0.8 . The other variants, in order of decreasing frequency, were $C S N 1 S 1{ }^{*} G(0.101)$ and $C S N 1 S 1{ }^{*} C(0.082)$. Moreover, a new IEF pattern was identified, which seemingly indicated the presence of a novel CSN1S1 variant, tentatively named $C S N 1 S 1 * I$. For the other loci, a predominance of $C S N 2 * A^{2}(0.764), C S N 3 * B(0.609)$, and $L G B^{*} B(0.592)$ occurred. Four variants were found at $C S N 2$, with the $C S N 2 * B$ frequency greater than $A^{1}$ (0.149 vs. 0.084 ). Only 1 cow carried the rare $C S N 2 * C$ allele at the heterozygous condition $\left(A^{2} C\right)$. The high frequency of milk protein variants positively associated with milk cheese-making aptitude is important for the genetic management of the breed (i.e., $C S N 3{ }^{*} B$, $C S N 2 * B$, and $L G B{ }^{*} B$; reviewed by Di Stasio and Mariani, 2000).

Figure 1 shows the novel IEF pattern, migrating at an intermediate position between $C S N 1 S 1^{*} B$ and CSN1S1*C. It was identified in 6 cows possibly heterozygous for a protein variant (here named as $I$ ) responsible for this pattern, and which could correspond to the X IEF pattern described by Kawamoto et al. (1992). In Nepalese $B$. taurus and $B$. taurus $\times B$. grunniens crosses, these authors found 2 unknown IEF variants of $\alpha_{\mathrm{s} 1}-\mathrm{CN}$, tentatively named $\mathrm{X}$ and $\mathrm{Y}$, which were not further characterized. The $\mathrm{X}$ variant migrated between $B$ and $C$, and could correspond to the CSN1S1*I variant observed in the Carora. The Y pattern showed a more anodic pattern if compared with $C S N 1 S 1 * B$, possibly fitting with $C S N 1 S 1{ }^{*} D$ or $C S N 1 S 1 * A$ on the basis of Figure 1 data.

Moreover, Ibeagha-Awemu (2003) already proposed the name of $C S N 1 S 1 * I$ for an IEF variant migrating at an intermediate position between $\operatorname{CSN} 1 S 1^{*} B$ and
C. She found CSN1S1*I in 3 Cameroon B. indicus breeds: White Fulani (allele frequency $=0.05$ ), Red Bororo (0.05), and Banyo Gudali (0.09). Full agreement was found between the IEF migration of CSN1S1*I from Carora and a reference sample carrying CSN1S1*I from the Banyo Gudali breed at the heterozygous condition with the $C$ variant (Figure 1). Molecular characterization of $C S N 1 S 1 * I$ from different breeds is in progress. Three of the 6 Carora cows carrying $C S N 1 S 1^{*} I$ were half-sisters, descending from the same sire. This is a clear hint of the genetic origin of the IEF variant. The occurrence of $C S N 1 S 1^{*} I$ in the Carora could indicate a $B$. indicus introgression, in agreement with mating nowadays between Carora bulls and $B$. indicus cows (Cerutti et al., 2006). This variant was also found at the heterozygous condition in one sample from a previous typing of 40 Carora cows for milk protein polymorphisms carried out by IEF in 2001 (Budelli and Caroli, unpublished results).

As for $C S N 1 S 1^{*} G$, we would point out that IEF allows the detection of heterozygous samples quite well, which are characterized by the occurrence of several lighter bands in the position corresponding to the $B$ variant, together with the 2 more marked bands resulting from $C S N 1 S 1 * C$. Thus, 6 samples were typed as $C G$ by IEF, and all were confirmed at the DNA level. The detection of the $B G$ and $G G$ genotypes at the protein level is difficult because of possible confounding with the $B B$ genotype. The attribution of the $25 B G$ and $3 G G$ genotypes was carried out at the DNA level.

The detection of the $C S N 1 S 1{ }^{*} G$ variant at a rather high frequency is noteworthy because, until now, only a few works have taken into account this variant in studies on bovine CSN1S1 variability. Rando et al. 
Table 3. Frequencies of $\alpha_{\mathrm{s} 1} \mathrm{CN}$ (CSN1S1), $\beta$-CN (CSN2), and $\kappa$-CN (CSN3) haplotypes in the Carora breed $(\mathrm{n}=173)^{1}$

\begin{tabular}{|c|c|c|c|c|c|c|}
\hline \multicolumn{3}{|c|}{ Haplotype $^{2}$} & \multicolumn{3}{|c|}{ Frequency } & \multirow[b]{2}{*}{$\mathrm{D} \%{ }^{5}$} \\
\hline CSN1S1 & CSN2 & CSN3 & $\mathrm{AF}^{3}$ & $\mathrm{IF}^{4}$ & $\mathrm{AF}-\mathrm{IF}$ & \\
\hline$B$ & $A^{2}$ & $B$ & 0.418 & 0.404 & 0.014 & 3.50 \\
\hline$B$ & $A^{2}$ & $A$ & 0.213 & 0.240 & -0.027 & -11.32 \\
\hline$B$ & $B$ & $B$ & 0.069 & 0.080 & -0.011 & -13.41 \\
\hline B & $A^{1}$ & $A$ & 0.068 & 0.022 & 0.046 & 204.46 \\
\hline$C$ & $A^{2}$ & $B$ & 0.062 & 0.042 & 0.020 & 47.56 \\
\hline$B$ & $B$ & $A$ & 0.059 & 0.048 & 0.012 & 24.58 \\
\hline$G$ & $A^{2}$ & $B$ & 0.053 & 0.039 & 0.014 & 35.14 \\
\hline$C$ & $A^{2}$ & $A$ & 0.023 & 0.025 & -0.002 & -9.98 \\
\hline$G$ & $B$ & $B$ & 0.020 & 0.008 & 0.012 & 159.08 \\
\hline$G$ & $A^{2}$ & $A$ & 0.005 & 0.023 & -0.018 & -78.19 \\
\hline$B$ & $A^{1}$ & $B$ & 0.004 & 0.038 & -0.034 & -89.44 \\
\hline$G$ & $B$ & $A$ & 0.003 & 0.005 & -0.002 & -44.57 \\
\hline$C$ & $B$ & $A$ & 0.002 & 0.005 & -0.003 & -60.18 \\
\hline$C$ & $B$ & $B$ & 0.000 & 0.008 & -0.008 & -99.54 \\
\hline$C$ & $A^{1}$ & $A$ & 0.000 & 0.002 & -0.002 & -99.91 \\
\hline$G$ & $A^{1}$ & $A$ & 0.000 & 0.002 & -0.002 & -99.95 \\
\hline$C$ & $A^{1}$ & $B$ & 0.000 & 0.004 & -0.004 & -100.00 \\
\hline$G$ & $A^{1}$ & $B$ & 0.000 & 0.004 & -0.004 & -100.00 \\
\hline
\end{tabular}

\footnotetext{
${ }^{1}$ Frequencies were estimated by the EH program (Xie and Ott, 1993), not considering allele frequencies lower than 0.05 .

${ }^{2}$ Haplotypes are listed in decreasing AF order.

${ }^{3} \mathrm{AF}=$ haplotype frequencies estimated by taking association into account.

${ }^{4} \mathrm{IF}=$ haplotype frequencies expected under the independence hypothesis.

${ }^{5} \mathrm{D} \%=[(\mathrm{AF}-\mathrm{IF}) / \mathrm{IF}] \%$.
}

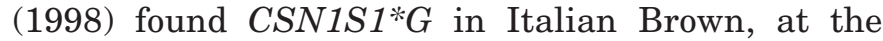
rather high frequency of 0.125 , as well as in 3 local Italian breeds: Agerola (0.033), Podolian (0.033), and Modicana (0.017). They did not find the $C S N 1 S^{*} G$ allele in Italian-Friesian, Italian Red Pied, Jersey, or Reggiana. Ceriotti et al. (2004) did not find $C S N 1 S 1{ }^{*} G$ in the different African cattle breeds either from $B$. taurus (Somba and Lagune) or B. indicus (Sudanese Zebu Peul, Azaouak, and Adamawa), whereas they found it again in the Modicana at a frequency of 0.02 , close to the value observed by Rando et al. (1998). The occurrence of $\operatorname{CSN} 1 S 1 * G$ in the Carora is a clear hint of the Brown Swiss origin of the breed. These molecular data agree with previous results obtained by immunological and biochemical markers (Ceriotti et al., 2003), which revealed, within B. taurus breeds, a higher closeness of Carora with Modicana and Brown Atlas, most probably because of the consistent presence of Brown Swiss genes in all of them.

Moreover, $C S N 1 S 1 * G$ could affect cheese-making properties. Mariani et al. (1995) found that the reduction in $\alpha_{\mathrm{s} 1}$-CN caused by $C S N S 1^{*} G$ was associated with an increased relative content of $\kappa$-CN, possibly improving stability of the CN micelle toward the coagulation action exerted by ionic calcium. Nevertheless, the lower $\alpha_{\mathrm{s} 1}$-CN content could negatively affect the first phase of ripening in cheeses produced by rennet coagulation, because $\alpha_{\mathrm{s} 1}-\mathrm{CN}$ is the substrate for the nonspecific action of chymosin (Mariani et al., 1995). The particular variation at the CSN1S1 level suggests the importance of developing studies in the CSN1S1 noncoding sequences. Molecular analyses should also be carried out at the promoter level, where interesting relationships have been observed between particular polymorphisms and milk production traits (Prinzenberg et al., 2003).

Haplotype frequencies at the CSN1S1-CSN2-CSN3 gene complex are shown in Table 3. A total of 18 possible haplotypes resulted from the combination of the 3-3-2 alleles considered. The haplotype frequencies expected under the independence hypothesis (IF) were strongly different from the haplotype frequencies estimated by the $\mathrm{EH}$ program taking association into account (AF). Only 7 haplotypes had AF values $>0.05$, and these accounted for a cumulative AF frequency of 0.944 . The $C S N 1 S 1{ }^{*} G$ variant occurred mainly within the $G-A^{2}-B(0.053)$ and $G-B-B(0.020)$ haplotypes, and was associated mainly with $C S N 3^{*} B$. In fact, the sum of the AF values of the $C S N 1 S 1{ }^{*} G+C S N 3 * B$ combinations was 0.073 , versus 0.008 for the $C S N 1 S 1 * G+$ CSN3*A combinations. Linkage disequilibrium was highly significant ( $\chi_{\text {[df } 17]}^{2}=40.28, P<0.0012$ ). The greatest positive differences between $\mathrm{AF}$ and IF values $(\mathrm{AF}-\mathrm{IF})$, expressed as the percentage of $\mathrm{AF}-\mathrm{IF}$ on 
IF (D\%), were found for $B-A^{1}-A, G-B-B, C-A^{2}-B, G-A^{2}$ $B$, and $B-B-B$. The predominant $B-A^{2}-B$ haplotype had an $\mathrm{AF}$ value close to IF, whereas AF was slightly lower than IF for the second and third most common haplotypes $\left(B-A^{2}-A\right.$ and $\left.B-B-B\right)$. All 9 of the least common haplotypes had negative AF - IF values.

The haplotype frequencies are similar to those observed in Italian Brown Swiss (Boettcher et al., 2004), except for the $C S N 1 S 1^{*} G$ allele, which was not typed in that study. As in the Carora, the most common haplotype was $B-A^{2}-B$ (frequency $=0.5$ ), which was not found to be associated with significant effects on any milk traits in the Italian Brown. The haplotype with the most favorable effect on protein concentration and a negative effect on milk yield was $C-A^{2}-B$, with a frequency of 0.05 (Boettcher et al., 2004), very close to the frequency of 0.062 found in the Carora. Thus, the contribution of Brown Swiss to the Carora breed is clearly reflected in the $\mathrm{CN}$ haplotype structure.

The occurrence of the $G$ variant at a rather high frequency is of interest for selection within the Carora breed because of the negative association of this variant with the synthesis of the specific protein. From a cheese-making point of view, the rather high incidence of the variant in the Carora breed could improve milkclotting parameters but negatively affect ripening conditions in cheese produced by rennet coagulation (Mariani et al., 1995). Thus, milk protein typing plans should be routinely carried out in the breed, and the occurrence of the $C S N 1 S^{*} G$ variant should be maintained at a low level. Moreover, the IEF pattern named as $I$ is another indication of the complexity revealed at the CSN1S1 level in the Carora breed, and may suggest $B$. indicus introgression into the Carora breed. In fact, until now this variant has been described only in B. indicus (Ibeagha-Awemu, 2003). Finally, the study of polymorphism in CSN1S1 noncoding sequences, in particular the $5^{\prime}$ and $3^{\prime}$ flanking regions, should be carried out to better explain the variability observed at the protein level, with the aim both of answering questions regarding the possible $B$. indicus introgression, and of identifying effects on milk production traits that could be exploited for genetic improvement of the Carora.

\section{ACKNOWLEDGMENT}

We thank Georg Erhardt for the kind gift of $\alpha_{\mathrm{s} 1}{ }^{-} \mathrm{CN}$ reference samples.

\section{REFERENCES}

ASOCRICA (Asociación Venezolana de Criadores de Ganado Carora). 2007. Raza Carora. http://www.razacarora.com/ Accessed April 26, 2007.
Boettcher, P. J., A. Caroli, A. Stella, S. Chessa, E. Budelli, F. Canavesi, S. Ghiroldi, and G. Pagnacco. 2004. Effects of casein haplotypes on production traits in Italian Holstein and Brown cattle. J. Dairy Sci. 87:4311-4317.

Ceriotti, G., A. Caroli, R. Rizzi, and C. Crimella. 2003. Genetic relationships among taurine (Bos taurus) and zebu (Bos indicus) populations as revealed by blood groups and blood proteins. J. Anim. Breed. Genet. 120:57-67.

Ceriotti, G., D. Marletta, A. Caroli, and G. Erhardt. 2004. Milk protein polymorphism in taurine (Bos taurus) and zebu (Bos indicus) populations bred in hot climate. J. Anim. Breed. Genet. 121:404-415.

Cerutti, F., J. C. Alvarez, and R. Rizzi. 2006. Development of the Carora breed. Proc. in 8th World Congr. Genet. Appl. Livest. Prod., Belo Horizonte, Brazil. Commun. No. 00-06.

Di Stasio, L., and P. Mariani. 2000. The role of protein polymorphism in the genetic improvement of milk production. Zootec. Nutr. Anim. 26:69-90.

Eigel, W. N., J. E. Butler, C. A. Ernstrom, H. M. Farrell Jr., V. R. Harwalkar, R. Jenness, and R. M. Whitney. 1984. Nomenclature of proteins of cow's milk: Fifth revision. J. Dairy Sci. 67:1599-1631.

Erhardt, G. 1993. A new $\alpha_{\mathrm{s} 1}$-casein allele in bovine milk and its occurrence in different breeds. Anim. Genet. 24:65-66.

Erhardt, G., J. Juszczak, L. Panicke, and H. Krick-Saleck. 1998. Genetic polymorphism of milk proteins in Polish Red Cattle: A new genetic variant of $\beta$-lactoglobulin. J. Anim. Breed. Genet. 115:63-71.

Farrell, H. M., Jr., R. Jimenez-Flores, G. T. Bleck, E. M. Brown, J. E. Butler, L. K. Creamer, C. L. Hicks, C. M. Hollar, K. F. NgKwai- Hang, and H. E. Swaisgood. 2004. Nomenclature of the proteins of cows' milk: Sixth edition. J. Dairy Sci. 87:1641-1674.

Formaggioni, P., A. Summer, M. Malacarne, and P. Mariani. 1999. Milk protein polymorphism: Detection and diffusion of the genetic variants in Bos genus. Ann. Fac. Med. Vet. Univ. Parma 127-165.

Grosclaude, F., M. F. Mahé, G. Brignon, L. Di Stasio, and R. Jeunet. 1987. A Mendelian polymorphism underlying quantitative variations of goat $\alpha_{\mathrm{s} 1}$-casein. Genet. Sel. Evol. 19:399-412.

Grosclaude, F., M. F. Mahé, J. C. Mercier, J. Bonnemaire, and J. H. Teissier. 1976. Polymorphisme des lactoprotéines de bovinés Népalais. I. Mise en évidence, chez le yak, et caractérisation biochimique de deux nouveaux variants: $\beta$-Lactoglobuline $\mathrm{D}^{\text {yak }}$ et caséine $\alpha_{\mathrm{s} 1}$-E. Ann. Genet. Sel. Anim. 8:461-479.

Grosclaude, F., J. Pujolle, J. Garnier, and B. Ribadeau-Dumas. 1966. Mise en évidence de deux variants supplémentaires des protéines du lait de vache: $\alpha_{\mathrm{s} 1}-\mathrm{CnD}$ et $\mathrm{LgD}$. Ann. Biol. Anim. Biochem. Biophysique 6:215-222.

Ibeagha-Awemu, E. M. 2003. Biochemical and molecular characterisation of cattle breeds of Cameroon and Nigeria. PhD diss. Justus-Liebig University, Giessen, Germany.

Jansá-Pérez, M., C. Leroux, A. Sánchez-Bonastre, and P. Martin. 1994. Occurrence of a LINE sequence in the 3'UTR of the goat $\alpha_{\mathrm{s} 1}$-casein E-encoding allele associated with a reduced protein synthesis level. Gene 147:179-187.

Kawamoto, Y., T. Namikawa, A. Adachi, T. Amano, T. Shotake, T. Nishida, Y. Hayashi, B. Kattel, and H. B. Rajubhandary. 1992. A population genetic study on yaks, cattle and their hybrids in Nepal using milk protein variations. Anim. Sci. Technol. 63:563-575.

Lundén, A., M. Nilsson, and L. Janson. 1997. Marked effect of $\beta$ lactoglobulin polymorphism on the ratio of casein to total protein in milk. J. Dairy Sci. 80:2996-3005.

Mahé, M. F., G. Miranda, R. Queval, A. Bado, P. S. Zafindrajaona, and F. Grosclaude. 1999. Genetic polymorphism of milk proteins in African Bos taurus and Bos indicus populations. Characterization of variants $\alpha_{\mathrm{s} 1}-\mathrm{Cn}$. $\mathrm{H}$ and $\kappa$-Cn. J. Genet. Sel. Evol. 31:239-253.

Mariani, P., A. Anghinetti, P. Serventi, and E. Fossa. 1993. Frazionamento della caseina mediante RP-HPLC: Sulla osservazione 
di alcuni latti individuali caratterizzati da una bassa proporzione di $\alpha_{\mathrm{s} 1}$-caseina in vacche di razza Bruna. Ind. Latte 29:75-85.

Mariani, P., A. Summer, A. Anghinetti, C. Senese, P. Di Gregorio, A. Rando, and P. Serventi. 1995. Effects of the $\alpha_{\mathrm{sl}^{-}} \mathrm{CN}$ G allele on the percentage distribution of caseins $\alpha_{\mathrm{s} 1^{-}}, \alpha_{\mathrm{s} 2^{-}}, \beta$-, and $\kappa$ - in Italian Brown cows. Ind. Latte 31:3-13.

Prinzenberg, E. M., C. Weimann, H. Brandt, J. Bennewitz, E. Kalm, M. Schwerin, and G. Erhardt. 2003. Polymorphism of the bovine CSN1S1 promoter: Linkage mapping, intragenic haplotypes, and effect on milk production traits. J. Dairy Sci. 86:2696-2705.

Rando, A., P. Di Gregorio, L. Ramunno, P. Mariani, A. Fiorella, C. Senese, D. Marletta, and P. Masina. 1998. Characterization of the $\mathrm{CSN} 1 \mathrm{~A}^{\mathrm{G}}$ allele of the bovine $\alpha_{\mathrm{S} 1}$-casein locus by the insertion of a relict of a long interspersed element. J. Dairy Sci. $81: 1735-1742$.

Rando, A., L. Ramunno, P. Di Gregorio, R. Davoli, and P. Masina. 1992. A rare insertion in the bovine $\alpha_{\mathrm{s} 1}$-casein gene. Anim. Genet. 23:55.

Thompson, M. P., C. A. Kiddy, L. Pepper, and C. A. Zittle. 1962. Variations in the $\alpha_{\mathrm{s}}$-casein fraction of individual cow's milk. Nature 195:1001-1002.

Xie, X., and J. Ott. 1993. Testing linkage disequilibrium between a disease gene and marker loci. Am. J. Hum. Genet. 53:1107. 